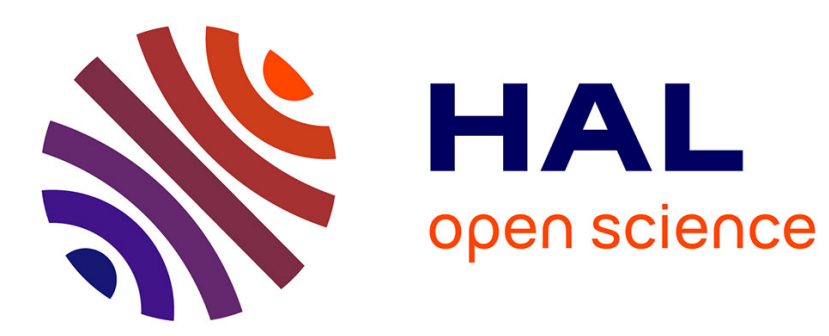

\title{
Platforms for the design of platforms: collaborating in the unknown
}

\author{
Armand Hatchuel, Pascal Le Masson, Benoit Weil
}

\section{To cite this version:}

Armand Hatchuel, Pascal Le Masson, Benoit Weil. Platforms for the design of platforms: collaborating in the unknown. Platforms, Market and Innovation, Edward Elgar, pp.273-305, 2010. hal-00696949

\section{HAL Id: hal-00696949}

https://hal-mines-paristech.archives-ouvertes.fr/hal-00696949

Submitted on 14 May 2012

HAL is a multi-disciplinary open access archive for the deposit and dissemination of scientific research documents, whether they are published or not. The documents may come from teaching and research institutions in France or abroad, or from public or private research centers.
L'archive ouverte pluridisciplinaire HAL, est destinée au dépôt et à la diffusion de documents scientifiques de niveau recherche, publiés ou non, émanant des établissements d'enseignement et de recherche français ou étrangers, des laboratoires publics ou privés. 
Table 2: Main Features of the Design Process

\begin{tabular}{|c|c|c|c|c|}
\hline & Biomaterials & ITRS & Cockpit & Biotech \\
\hline Goals & Build a new industry & Support industry growth & $\begin{array}{l}\text { Industry growth through innovative } \\
\text { cockpits }\end{array}$ & Build new research fields \\
\hline Inputs & $\begin{array}{l}\text { "Building with Hemp" }+ \text { a list of } \\
\text { potential partners }+ \text { some isolated } \\
\text { experiments }\end{array}$ & $\begin{array}{l}\text { Several issues regarding concepts and } \\
\text { processes in the non-competitive } \\
\text { domain }+ \text { main industry players } \\
\text { (suppliers, manufacturers, users) }\end{array}$ & $\begin{array}{l}\text { "Future cockpits". A single player at the } \\
\text { beginning: a cockpit supplier. }\end{array}$ & $\begin{array}{l}\text { New instrument concept } \quad \text { (actionable } \\
\text { phenomenon) }+ \text { an original research question }\end{array}$ \\
\hline $\begin{array}{l}\text { New } \\
\text { capabilities }\end{array}$ & $\begin{array}{l}\text { Yes: characterization of materials, } \\
\text { processes, usages, the construction } \\
\text { business }\end{array}$ & Yes & $\begin{array}{l}\text { Yes: on aircraft integrator utility and } \\
\text { constraints, on aircraft companies, on } \\
\text { pilots, on technologies, etc. }\end{array}$ & $\begin{array}{l}\text { Yes: on the research question (animals and } \\
\text { pathologies, etc.), on the instruments } \\
\text { underlying the phenomena, etc. }\end{array}$ \\
\hline Phases & $\begin{array}{l}\text { Sub-sets of one or a few partners } \\
\text { conducting or financing experiments, } \\
\text { research projects, validation projects, } \\
\text { communication projects }\end{array}$ & $\begin{array}{l}\text { Each partner conducts (or sub- } \\
\text { contracts) individual investigations on } \\
\text { clear, well-identified technological } \\
\text { issues }\end{array}$ & $\begin{array}{l}\text { In-house exploration of conceptual } \\
\text { alternatives for cockpits. } \\
\text { Design of cockpit simulators enabling } \\
\text { collective explorations with aircraft } \\
\text { integrator, companies and pilots }\end{array}$ & $\begin{array}{l}\text { An original experiment with new instrument } \\
\text { facility (+publication) } \\
\text { Other experiments with other researchers, } \\
\text { based on the same instrument principle. } \\
\text { Improvement and innovation on the instrument } \\
\text { principles }\end{array}$ \\
\hline Coordination & $\begin{array}{l}\text { Regular steering committee sharing } \\
\text { results of the explorations, listing } \\
\text { open questions to be explored, } \\
\text { discussing possible ways and } \\
\text { collective facility for each related } \\
\text { exploration }\end{array}$ & $\begin{array}{l}\text { Three conferences per year, with all } \\
\text { ITRS group members. Working groups } \\
\text { responsible for one process issue. } \\
\text { Each group updates its related } \\
\text { roadmap, identifies emerging solutions } \\
\text { and pending questions }\end{array}$ & $\begin{array}{l}\text { Two levels: } \\
\text { - inside company: gathering results, } \\
\text { orienting explorations and choosing } \\
\text { partners } \\
\text { - simulator level: steering committee } \\
\text { sharing results with main partners }\end{array}$ & $\begin{array}{l}\text { Two levels: } \\
\text { - device level: steering committee (instrument } \\
\text { manager + pioneer researchers) choosing } \\
\text { relevant experiment to be accepted on the } \\
\text { experimental device } \\
\text { - experiment level: regular meetings between } \\
\text { instrument manager and researcher }\end{array}$ \\
\hline Resources & $\begin{array}{l}\text { Classic association funding; partners } \\
\text { pay for their own explorations. }\end{array}$ & $\begin{array}{l}\text { Members pay for their own } \\
\text { explorations. Collective expenses } \\
\text { (meeting) shared }\end{array}$ & $\begin{array}{l}\text { Cockpit supplier provides the simulation } \\
\text { bench }\end{array}$ & $\begin{array}{l}\text { Initial fund-raising through research contracts. } \\
\text { Experimental devices then financed through } \\
\text { public funding or foundations }\end{array}$ \\
\hline $\begin{array}{l}\text { Leading } \\
\text { partners }\end{array}$ & $\begin{array}{l}\text { Leading builders, architects, hemp } \\
\text { transformers, lime suppliers, grouped } \\
\text { in an association "Building with } \\
\text { Hemp". Growing number of members } \\
\text { in the association. Limited and } \\
\text { varying number of members taking } \\
\text { part in the association's steering } \\
\text { committee (decreasing first and then } \\
\text { increasing) }\end{array}$ & $\begin{array}{l}\text { Main players of semiconductor industry } \\
\text { (process suppliers, manufacturers, } \\
\text { users such as cell phone } \\
\text { manufacturers, PC integrators, etc.). } \\
\text { Open participation. } \\
\text { ITRS groups are led by designers } \\
\text { working for } \\
\text { manufacturers. }\end{array}$ & $\begin{array}{l}\text { Cockpit designer alone at the } \\
\text { beginning. Then component suppliers, } \\
\text { aircraft integrator, aircraft companies, } \\
\text { pilots also participate (slow } \\
\text { enlargement). } \\
\text { Simulation level steering committee } \\
\text { limited to aircraft integrator and cockpit } \\
\text { supplier. }\end{array}$ & $\begin{array}{l}\text { Limited to one research pioneer and } \\
\text { instrument pioneer at the beginning. Then } \\
\text { extended to other researchers (in the same } \\
\text { and in different fields), to the instrument } \\
\text { manufacturer(s), etc. } \\
\text { Selection of participants to use the exploratory } \\
\text { device. } \\
\text { Steering committee limited to pioneers. }\end{array}$ \\
\hline Platform & Industry platform $=$ professional rules & Industry platform = Production process & Industry platform $=$ validation bench for & Research field platform $=$ new services for \\
\hline
\end{tabular}




\begin{tabular}{|c|c|c|c|c|}
\hline output & $\begin{array}{l}\text { for new house-building. } \\
\text { Core }=\text { choice of materials, process } \\
\text { parameters, etc. } \\
\text { Networks }=\text { material providers }+ \\
\text { builders }+ \text { architects }+ \text { building } \\
\text { owners } \\
\text { Value }=\text { new market (thanks to state } \\
\text { guarantees for insurance purposes) }+ \\
\text { cross-sided network effects. }\end{array}$ & $\begin{array}{l}\text { platform for next semiconductor } \\
\text { generation } \\
\text { Core = main technology process } \\
\text { choices, performance level, etc. } \\
\text { Networks = production process } \\
\text { suppliers, manufacturers, users. } \\
\text { Value = decrease investment risks for } \\
\text { machines suppliers; direct } \\
\text { semiconductor users' design efforts. }\end{array}$ & $\begin{array}{l}\text { cockpit components } \\
\text { Core = bench, evaluation rules, etc. } \\
\text { Networks = components supplier, } \\
\text { cockpit integrator, aircraft integrator, } \\
\text { aircraft companies, pilots, etc. } \\
\text { Value = leverage innovative technology } \\
\text { in cockpit components, enable } \\
\text { innovative cockpit with clear user value } \\
\text { for companies and pilots. }\end{array}$ & $\begin{array}{l}\text { measurement/ analysis to support efficient } \\
\text { research in a new field } \\
\text { Core = routinized services, including self- } \\
\text { service; } \\
\text { Networks = research community, instrument } \\
\text { makers; } \\
\text { Value = easy access of researchers to a new } \\
\text { research field, large market for new, routinized } \\
\text { instruments }\end{array}$ \\
\hline $\begin{array}{l}\text { Other } \\
\text { outputs }\end{array}$ & $\begin{array}{l}\text { Strategic view of the field (other hemp } \\
\text { building opportunities) } \\
\text { Competencies }\end{array}$ & $\begin{array}{l}\text { Strategic view of future, emerging } \\
\text { platforms, at multiple time horizons }\end{array}$ & $\begin{array}{l}\text { Representation of alternative cockpit } \\
\text { concepts } \\
\text { Increase knowledge on user-value }\end{array}$ & $\begin{array}{l}\text { For pioneers: better understanding of the } \\
\text { instrument potential applications and the } \\
\text { possible research paths }\end{array}$ \\
\hline Rights & $\begin{array}{l}\text { No fees on professional rules. Patents } \\
\text { obtained during the exploration } \\
\text { process are owned by the explorers }\end{array}$ & $\begin{array}{l}\text { ITRS road map is available for free. } \\
\text { IP obtained during the exploration is the } \\
\text { property of the explorer. }\end{array}$ & $\begin{array}{l}\text { Limited access to the simulator. } \\
\text { IP for the explorers (either cockpit } \\
\text { designer alone or cockpit designer + } \\
\text { aircraft integrator) }\end{array}$ & $\begin{array}{l}\text { Selective access to the experimental device. } \\
\text { IP for explorers, shared with the instrument } \\
\text { maker }\end{array}$ \\
\hline
\end{tabular}

